\title{
Estradiol Reduces Calcium Currents in Rat Neostriatal Neurons via a Membrane Receptor
}

\author{
Paul G. Mermelstein, ${ }^{1,3}$ Jill B. Becker, ${ }^{1,2}$ and D. James Surmeier ${ }^{3}$ \\ ${ }^{1}$ Neuroscience and Reproductive Sciences Programs, and 2Department of Psychology, University of Michigan, Ann \\ Arbor, Michigan 48104, and ${ }^{3}$ Department of Anatomy and Neurobiology, College of Medicine, University of Tennessee, \\ Memphis, Tennessee 38163
}

Until recently, steroid hormones were believed to act only on cells containing intracellular receptors. However, recent evidence suggests that steroids have specific and rapid effects at the cellular membrane. Using whole-cell patch-clamp techniques, $17 \beta$-estradiol was found to reduce $\mathrm{Ba}^{2+}$ entry reversibly via $\mathrm{Ca}^{2+}$ channels in acutely dissociated and cultured neostriatal neurons. The effects were sex-specific, i.e., the reduction of $\mathrm{Ba}^{2+}$ currents was greater in neurons taken from female rats. $17 \beta$-Estradiol primarily targeted L-type currents, and their inhibition was detected reliably within seconds of administration. The maximum reduction by $17 \beta$-estradiol occurred at picomolar concentrations. $17 \beta$-Estradiol conjugated to bovine serum albumin also reduced $\mathrm{Ba}^{2+}$ currents, suggest-

Estradiol, as well as other steroid hormones, is known to alter gene transcription via intracellular receptors (Pfaff, 1980; Pfaff and Schwartz-Giblin, 1988; Carson-Jurica et al., 1990). As expected, estrogen receptors are found in regions often associated with reproduction, such as the mammalian hypothalamus and utcrus (Stancel ct al., 1973; Stumpf and Sar, 1978; McEwen, 1979). However, steroid hormones also act in regions that do not contain intracellular steroid receptors. These effects often are too fast to be attributed to genomic activation and are believed to occur via stimulation of membrane receptors.

One region in which a membrane receptor may be important is the brain, where estradiol has rapid effects that are not readily attributable to traditional steroid receptors. For example, estradiol decreases the spontaneous firing of medial preoptic area neurons (Kelly et al., 1977) and increases the firing rate of pituitary cells (Dufy et al., 1979). Estradiol also potentiates EPSPs in the hippocampus (Wong and Moss, 1991, 1992) and Glu responses in the cerebellum (Smith et al., 1987, 1989) while hyperpolarizing medial amygdala neurons (Nabekura et al., 1986; Minami et al., 1990). In the guinea pig, estrogen suppresses $\mu$-opioid- and $\mathrm{G} \Lambda \mathrm{B} \Lambda_{\mathrm{B}}$-based hyperpolarization of

\footnotetext{
Received June 13, 1995; revised Sept. 18, 1995; accepted Oct. 16, 1995.

This work was supported by National Institute of Neurobiological Disorders and Stroke Grant NS-28889 to D.J.S. and National Science Foundation Grant BNS 9021966 to J.B.B. P.G.M. was supported by NIMH National Research Service. Award MH10556. We thank Neurex for its generous gift of SNX-230 ( $\omega$-CTXMVIIC). We also thank Dr. L. Dudkin for her technical help, Drs. H. Akil, R. Albin, and R. Hume for helpful discussions, and Dr. R. Meisel for critically reading this manuscript.

Correspondence should be addressed to Paul G. Mermelstein, Department of Anatomy and Neurobiology, University of Tennessee, Memphis, 855 Monroe Avenue, Memphis, TN 38163.

Copyright (c) 1996 Society for Neuroscience $0270-6474 / 96 / 160595-10 \$ 05.00 / 0$
}

ing that the effect occurs at the membrane surface. Dialysis with GTP $\gamma S$ prevented reversal of the modulation, suggesting that $17 \beta$-estradiol acts via G-protein activation. $17 \alpha$-Estradiol also reduced $\mathrm{Ba}^{2+}$ currents but was significantly less effective than 17 $\beta$-estradiol. Estriol and 4-hydroxyestradiol were found to reduce $\mathrm{Ba}^{2+}$ currents with similar efficacy to $17 \beta$-estradiol, whereas estrone and 2-methoxyestriol were less effective. Tamoxifen also reduced $\mathrm{Ba}^{2+}$ currents but did not occlude the effect of $17 \beta$-estradiol. These results suggest that at physiological concentrations, $17 \beta$-estradiol can have immediate actions on neostriatal neurons via nongenomic signaling pathways.

Key words: estradiol; neostriatum; patch clamp; $\mathrm{Ca}^{2+}$ current; estrogen receptor; neuromodulation; steroid; nongenomic hypothalamic arcuate neurons (Kelly et al., 1992). Moreover, estrogen directly potentiates $\mathrm{K}^{+}$-stimulated dopamine release in rat nucleus accumbens (Thompson and Moss, 1994).

Another target of estrogen that lacks intracellular estrogen receptors is the adult neostriatum (Pfaff and Keiner, 1973; Stumpf and Sar, 1978; Simerly et al., 1990). Administration of estradiol in vivo potentiates the induced release of dopamine and rotational behavior (Becker, 1990a,b; Castner et al., 1993). Pulsatile administration of estradiol in vitro rapidly stimulates neostriatal dopamine release (Becker et al., 1990a). Estrogen pretreatment increases the firing rate of neostriatal neurons in response to dopamine (Arnauld et al., 1981), possibly via changes in $D_{1} / D_{2}$ dopamine-receptor coupling (Demotes-Mainard et al., 1990) or dopamine-receptor binding (Gordon and Perry, 1983; Clopton and Gordon, 1986; Levesque and Di Paolo, 1988; Tonnacr ct al., 1989; Bazzett and Becker, 1994). Moreover, estrogen implanted directly into the neostriatum enhances sensorimotor performance (Becker et al., 1987). Many of these effects of estradiol on the neostriatum are rapid, with the earliest measured changes occurring within $15 \mathrm{~min}$ of steroid administration (Levesque and $\mathrm{Di}$ Paolo, 1988).

Although the actions of estradiol on neostriatal functioning are widespread, the mechanism by which estradiol acts is unclear. Intracellular estrogen receptors have been reported in the neostriatum of newborn rat pups (Toran-Allerand et al., 1992), but they have not been reported in the adult. Moreover, the effects of estradiol within the neostriatum are too fast to be attributed to genome activation. The most parsimonious hypothesis is that estradiol affects the neostriatum via a membrane receptor. To test this, estradiol was applied to isolated neostriatal neurons while measuring voltage-gated $\mathrm{Ba}^{2+}$ currents. $\mathrm{Ba}^{2+}$ currents through $\mathrm{Ca}^{2+}$ channels were chosen as an assay because of 
A

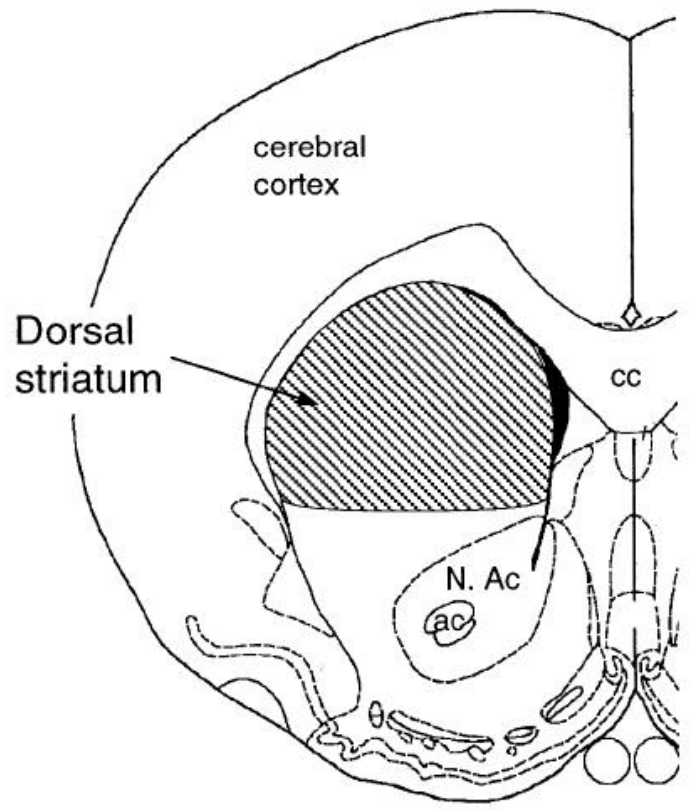

$\mathrm{B}$

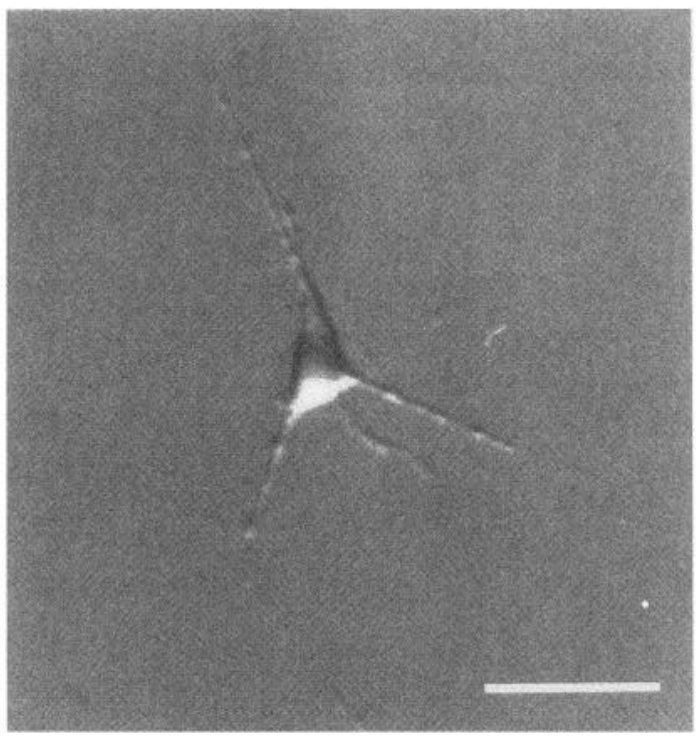

Figure 1. Recordings were taken from acutely isolated neurons of the dorsal neostriatum. $A$, Diagram of a coronal section through adult rat brain illustrating the neostriatal region isolated and dissociated for electrophysiological recording (adapted from Paxinos and Watson, 1986). B, Photomicrograph of a typical medium spiny neuron acquired via acute dissociation. Scale bar, $50 \mu \mathrm{m}$.

Figure 2. $17 \beta$-Estradiol inhibited $\mathrm{Ba}^{2+}$ currents in rat neostriatal neurons. $A$, Peak $\mathrm{Ba}^{2+}$ current measured in a neostriatal neuron taken from an 8 -week-old female rat. $17 \beta$-Estradiol $(17 \beta-E ; 100 \mathrm{pm})$ reduced peak current within seconds of administration. Episodes were obtained from a voltage-ramp protocol repeated once every $5 \mathrm{sec} . B$, Example traces taken from the time course illustrated in $A$. Cadmium $\left(+C d^{2+}\right.$; $200 \mu \mathrm{M}$ ) inhibits all current, demonstrating that only $\mathrm{Ca}^{2+}$ currents are being measured. Inset, $17 \beta$-Estradiol (1 pM) also was found to reduce the $\mathrm{Ba}^{2+}$ current in primary cultured neostriatal neurons $\left(10 \mathrm{mM} \mathrm{Ba}^{2+}\right.$ used as the charge carrier), suggesting that the steroid effect is not a function of the acute dissociation. $C$, Estradiol causes a larger inhibition of $\mathrm{Ba}^{2+}$ currents in 4-week-old females than in male rat neostriatal neurons $(p<0.0001$; concentrations of $17 \beta$-estradiol were $\geq 1 \mathrm{pm)}$. $D, E$, The current sensitive to $17 \beta$-estradiol (1 pM) activated relatively rapidly and inactivated slowly.
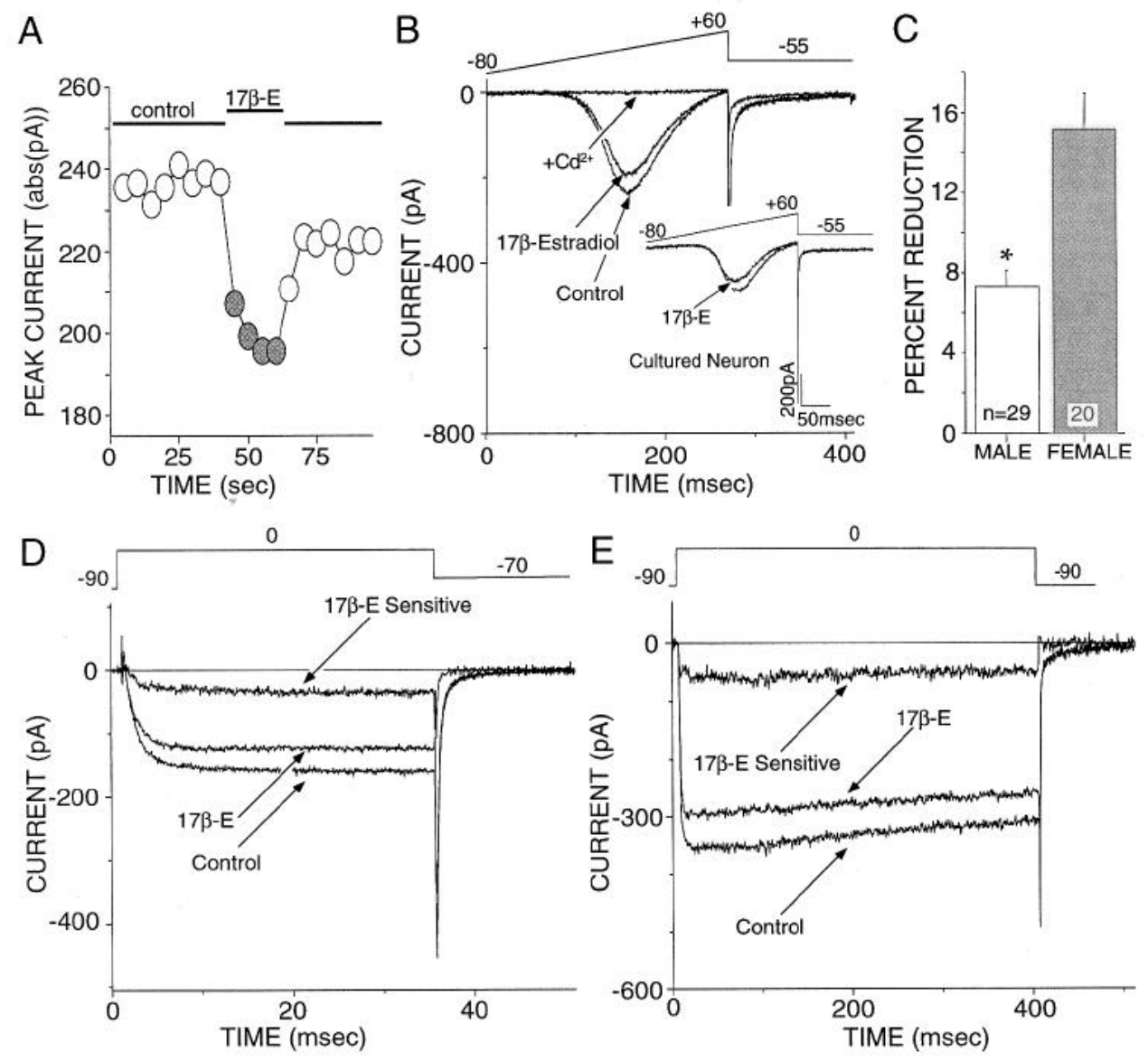

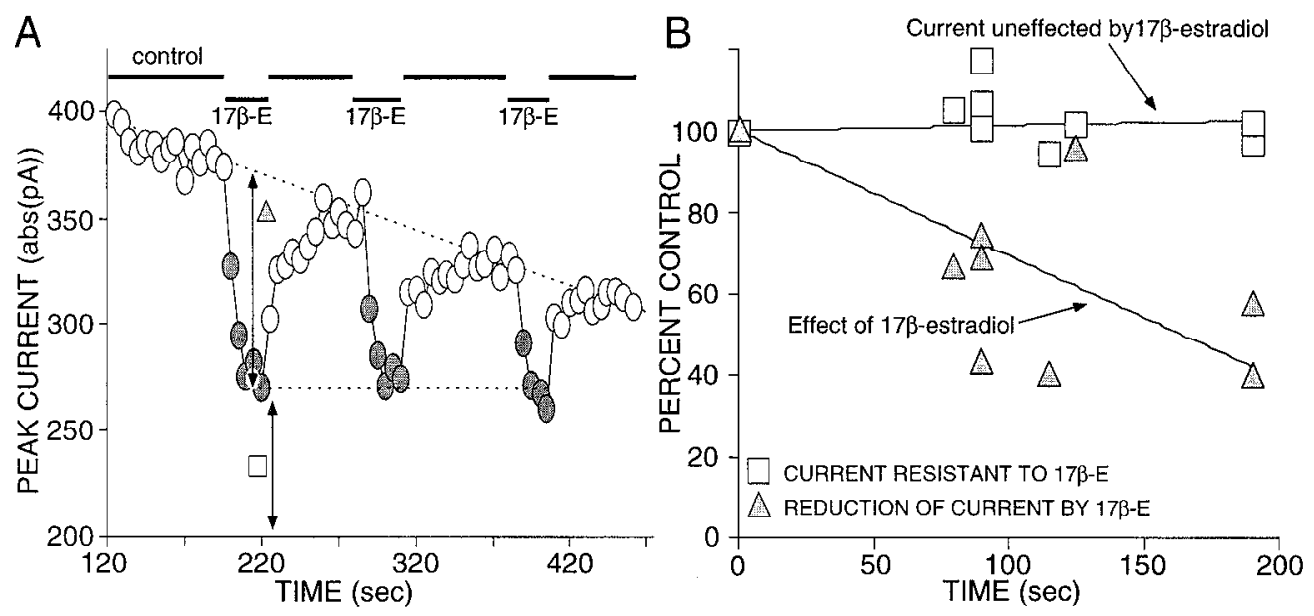

Figure 3. The modulation by $17 \beta-$ estradiol diminished with repeated application as a consequence of rundown of the estradiol-sensitive current. $A$, Plot of peak current as a function of time. $17 \beta$ Estradiol was applied successively. The magnitude of the nodulation (filled triangles) was estimated from a line fit to the control records (dotted line). The "resistant" current amplitude was defined as the amplitude of the current remaining in the presence of estradiol (open squares). $B$, Plot of modulated (filled triangles) and resistant current (open squares) for the time course in $A$ and for five other neurons. Note that the resistant current did not change with time, suggesting that the loss of the responsiveness to estradiol was a consequence of rundown in the estradiol-sensitive current. the importance of these channels in several cellular functions shown to be regulated by estrogen. The experiments reported in this study show that at physiologically relevant concentrations, $17 \beta$-estradiol acts in a steroid-specific manner to activate a G-protein-coupled membrane receptor that reduces L-type currents in rat neostriatal neurons. Furthermore, the effects were sex-specific, being larger in neurons taken from females than males.

\section{MATERIALS AND METHODS}

Acute-dissociation procedure. In most experiments, neostriatal neurons from prepubertal Sprague-Dawley female rats (4 weeks) were acutely dissociated using methods similar to those described previously (Surmeier et al., 1991, 1992). Neostriatal neurons also were taken from male rats of the same age and adult female $\sim 8$-week-old rats. Neostriatal neurons cultured from neonatal tissue also were studied. Results from neurons taken from one of these other preparations are so noted. For the acute dissociation, rats were anesthetized deeply with methoxyflurane and then decapitated. Brains were removed rapidly, blocked, sliced, and placed into a $4^{\circ} \mathrm{C}$ sucrose solution (in $\mathrm{mm}$ ): 250 sucrose, $2.5 \mathrm{KCl}, 1 \mathrm{NaHPO}_{1}\left(7 \mathrm{H}_{2} 0\right), 11$ glucose, $2 \mathrm{MgSO}_{1}, 2 \mathrm{CaCl}_{2}, 15$ HEPES, pH 7.4, $300 \mathrm{mOsm} / 1$. Tissue was cut $(400 \mu \mathrm{m}$ slices) with a Vibroslice (Campden Instruments, London, UK) while immersed in a $4^{\circ} \mathrm{C}$ low- $\mathrm{Ca}^{2+}(100 \mu \mathrm{M})$ HEPES-buffered salt solution (in $\mathrm{mM}$ ): 140 Na-isothionate, $2 \mathrm{KCl}, 4 \mathrm{MgCl}_{2}, 0.1 \mathrm{CaCl}_{2}, 23$ glucose, $15 \mathrm{HEPES}, \mathrm{pH}$ $7.4,300 \mathrm{mOsm} / \mathrm{l}$. Slices were incubated in a Cell-Stir chamber (Wheaton, Millville, NJ) from 1 to $4 \mathrm{hr}$ in a Earle's balanced salt solution (Sigma, St. Louis, MO) containing $100 \mu \mathrm{M}$ ascorbic acid (Sigma) and $100 \mu \mathrm{M} \mathrm{N} \mathrm{N}^{\mathrm{G}}$ - $n$-L-arginine (Sigma) while bubbled with $95 \%$ $\mathrm{O}_{2} / 5 \% \mathrm{CO}_{2}$ at room temperature. After removing slices from the first holding chamber, regions of the dorsal neostriatum were isolated under a dissecting microscope. Dissections were limited to regions rostral to the decussation of the anterior commissure, avoiding contamination from the globus pallidus (Fig. 1A). The dissected regions of the neostriatum then were placed into a second holding chamber containing $1.5 \mathrm{mg} / \mathrm{ml}$ protease (type XIV, Sigma) in HBSS (Sigma) at $35^{\circ} \mathrm{C}$. The enzyme chamber also contained $100 \mu \mathrm{M}$ ascorbic acid and $100 \mu \mathrm{M}$ $\mathrm{N}^{\mathrm{G}}-n$-L-arginine and was bubbled with $100 \% \mathrm{O}_{2}$. After $30 \mathrm{~min}$ of enzyme treatment, tissue was washed in low-Ca ${ }^{2+}$ HEPES-buffered saline and mechanically dissociated with a graded series of firepolished Pasteur pipettes. The cell suspension $(\sim 2 \mathrm{ml})$ then was plated into a $35 \mathrm{~mm}$ Lux Petri dish (Nunc, Naperville, IL), mounted on the stage of an inverted microscope, and allowed to settle.

Primary culture. For dissociation and subsequent culture of embryonic day 17 neostriatal neurons, we followed procedures described previously (Surmeier et al., 1988). Briefly, timed-pregnant female rats were anesthetized with methoxyflurane and cervically dislocated. The brains of pups were removed and placed into a $4^{\circ} \mathrm{C} \mathrm{Ca}^{2+}-, \mathrm{Mg}^{2+}$-free HBSS solution. Striata were removed under a dissecting microscope, washed, and placed into culture media (1:1 Ham's F12/EMEM, Gibco, Grand Island, NY) supplemented with fetal calf serum (10\%, HyClone, Logan, UT), insulin $(5 \mathrm{mg} / \mathrm{ml})$, penicillin $(50 \mathrm{U} / \mathrm{ml})$, and streptomycin $(50 \mathrm{mg} / \mathrm{ml}$; latter three from Sigma). The striata were triturated using a graded series of fire-polished Pasteur pipettes and then filtered to remove debris. Viability was determined with a trypan blue exclusion test. The cells were plated into Lux dishes at a density of $1-2 \times 10^{6}$ cells/dish. Cultures then were incubated in a $95 \%$ humidity $/ 5 \% \quad \mathrm{CO}_{2}$ atmosphere and fed twice/week with a basal media supplemented with $5 \%$ fetal calf serum and 5\% horse serum (HyClone) until recording ( $\sim 1$ week after plating). Before recording, the culture dishes were washed for $20 \mathrm{~min}$ with steroid-free bath solution. The same recording
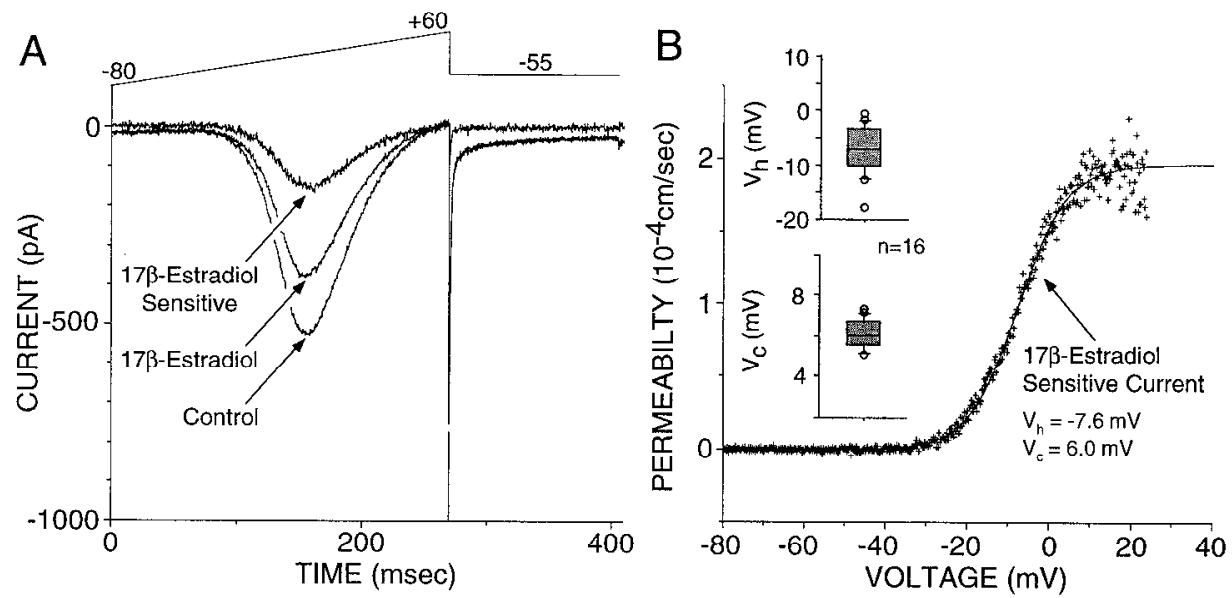

Figure 4. The voltage dependence of the $\mathrm{Ba}^{2+}$ current sensitive to $17 \beta$-estradiol indicated that the steroid inhibited a high-voltage-activated current. $A$, Administration of $17 \beta$-estradiol (100 pM) caused a reduction of $\mathrm{Ba}^{2+}$ current. The current sensitive to $17 \beta$-estradiol modulation was used to derive the permeability estimates shown in $B . B$, Permeability estimates were fit with a Boltzmann function. The variation in slope factor and half-maximal activation observed for the 16 neurons examined are shown in the inset box plots. 
protocols were used for cultured neurons as for neurons obtained via acute dissociation.

Whole-cell recordings. Whole-cell recordings were performed using standard techniques (Hamill et al., 1981; Surmeier et al., 1995). Electrodes were pulled from Corning 7052 glass (Corning, NY) and firepolished just before use. The internal recording solution typically consisted of (in InM): $190 \mathrm{~N}$-methyl-v-glucamine (NMG), 40 HEPES, 4 $\mathrm{MgCl}_{2}, 5$ BAPTA, 12 phosphocreatine, $2 \mathrm{Na}_{2}$ ATP, $0.2 \mathrm{Na}_{3}$-GTP or 0.4 $\mathrm{Na}_{3}-\mathrm{GTP} \gamma \mathrm{S}, 0.1$ leupeptin, $\mathrm{pH}$-adjusted to $7.2-7.3$ with $\mathrm{H}_{3} \mathrm{SO}_{4}, 265$ $275 \mathrm{mOsm} / \mathrm{l}$ |all obtained from Sigma except $\mathrm{H}_{3} \mathrm{SO}_{4}$, which was obtained from Fluka (Ronkonkoma, NY)]. Intracellular solutions of 0.1 and $10 \mathrm{~mm}$ BAPTA also were used occasionally with no apparent effect on the response by $17 \beta$-estradiol. The external recording solution consisted of (in mM): $135 \mathrm{NaCl}, 20 \mathrm{CsCl}, 1 \mathrm{MgCl}_{2}, 10 \mathrm{HEPES}, 0.001$ tetrodotoxin (TTX), $5 \mathrm{BaCl}_{2}$, pH-adjusted to 7.35 with $\mathrm{NaOH}, 300-309$ $\mathrm{mOsm} / \mathrm{l}$. Drugs were applied with a gravity-fed "sewer-pipe" system. The six application capillaries ( $\sim 150 \mu \mathrm{m}$ inner diameter) that made up the drug array were positioned a few hundred micrometers from the recorded cell. Solution changes were effected by altering the position of the array with a DC-drive system, manipulated by a PC-based controller (Newport-Klinger, La Jolla, CA). Solution changes were complete within 1-2 sec, as measured in (our) previous experiments by changes in reversal potential. Potentials were not corrected for the liquidjunction potential with the $\mathrm{NMG}-\mathrm{SO}_{4}$ internal, which was $\sim 7 \mathrm{mV}$. Recordings were performed at room temperature.

$17 \beta$-Estradiol (Sigma or Research Biochemicals, Natick, MA) was diluted in dimethylsulfoxide (DMSO; Sigma) as a concentrated stock (1 $\mathrm{mm}$ ) before each experiment and then serially diluted to its final concentration. Final concentration of DMSO typically was $\leq 10^{-6} \%$ (final concentration when using $100 \mathrm{pM}$ estradiol). We have found DMSO concentrations up to $0.01 \%$ to have no effect on neostriatal $\mathrm{Bi}^{2+}$ currents but, as a precaution, external media (including all control solutions) in initial experiments contained matched DMSO concentrations; solutions always were matched when final concentrations of DMSO were $\geq 10^{-5} \%$. In later experiments (including the occlusion studies performed with the $\mathrm{Ca}^{2+}$-channel blockers), extracellular recording solutions also contained $0.01 \%$ cytochrome $c$. Cytochrome $c$ was found to help keep the steroids in solution, resulting in a greater inhibition of $\mathrm{Ba}^{2+}$ current. Similar procedures were used when using $17 \alpha$-estradiol, tamoxifen, estrone, estriol, 2-methoxyestriol, and 4-hydroxyestradiol (Sigma). Comparisons between $17 \alpha$ - and $17 \beta$ estradiol were performed between neostriatal neurons; all other comparisons were done within the same cell with the order of steroid treatment randomly assigned. Phenol-red usually was added to several of the recording solutions as a $\mathrm{pH}$ indicator. Although phenol-red can have weak estrogenic effects via activation of the intracellular estrogen receptor in cell cultures (Berthois et al., 1986), removal of phenol-red in our solutions had no effect on estradiol reduction of $\mathrm{Ba}^{2+}$ currents. Estradiol conjugated to bovine serum albumin (E-BSA; Sigma) was made up as a concentrated stock $(52 \mathrm{~mm})$ in a standard Tris-buffer, aliquoted, and frozen $\left(-20^{\circ} \mathrm{C}\right)$ until use. The concentration of RSA was matched in all drug solutions when using E-BSA. For occlusion experiments, $\omega$-agatoxin-IVA ( $\omega$-AgTx-IVA; Peptides International, Louisville, KY), $\omega$ conotoxin-GVIA ( $\omega$-CTx-GVIA; Peninsula Labs, Bclmont, CA), and $\omega$-conotoxin-MVIIC ( $\omega$-CTx-MVIIC; Neurex, Menlo Park, CA) were made up as a concentrated stock $(0.100,1$, and $200 \mathrm{mM}$, respectively), aliquoted, and then diluted into external media. Nifedipine (Research Biochemicals) was dissolved as a concentrated stock (1 $\mathrm{mm}$ ) in $95 \%$ ethanol and then diluted. In experiments with nifedipine, final ethanol concentrations never exceeded $0.1 \%$. Ethanol concentrations were matched in all drug solutions.

Electrode resistances were $\sim 3-6 \mathrm{M} \Omega$ in bath. Recordings were obtained with an Axon Instruments 200 voltage-clamp controlled and monitored with pClamp (version 5.0 or 6.0, Axon Instruments, Foster City, $\mathrm{CA}$ ) running on a $486 \mathrm{PC}$ clone with a $125 \mathrm{kHz}$ interface (Axon). After formation of a $>1 \mathrm{G} \Omega$ seal, the membrane was ruptured. The electrode series resistance $(8-20 \mathrm{M} \Omega)$ was compensated $(80-85 \%)$ electronically and monitored periodically. Neostriatal recordings were from medium spiny neurons $(6-12 \mu \mathrm{m}$ diameter, whole-cell capacitance 3-9 $\mathrm{pF})$ that had short $(<50 \mu \mathrm{m})$ proximal dendrites (see Fig. $1 B$ ). Voltage control was assessed by examining the tail currents after strong depolarizations. Cells in which the tail current did not decay rapidly and smoothly were discarded.

Electrophysiological data typically were gathered using voltage ramps (Bargas et al., 1994). With ramps, cells were held at $-80 \mathrm{mV}$ and depolarized $(0.5 \mathrm{mV} / \mathrm{msec})$ to $+60 \mathrm{mV}$, at which point the cell was rapidly repolarized to $-55 \mathrm{mV}$ (for $\sim 100 \mathrm{msec}$ ). Ramp episodes were repeated once every $5 \mathrm{sec}$. Long $(\sim 400 \mathrm{msec})$ and short $(\sim 35 \mathrm{msec})$ steps also were used occasionally. Data analysis was performed on a Macintosh Quadra with either Axograph (version 2.0, Axon) or KaleidaGraph (version 3.0, Synergy Software, Reading, PA) software.

Statistics. Maximal reductions in $\mathrm{Ba}^{2+}$ currents in male and female neostriatal neurons were compared using a between-subjects $t$ test. Similar

\section{A}

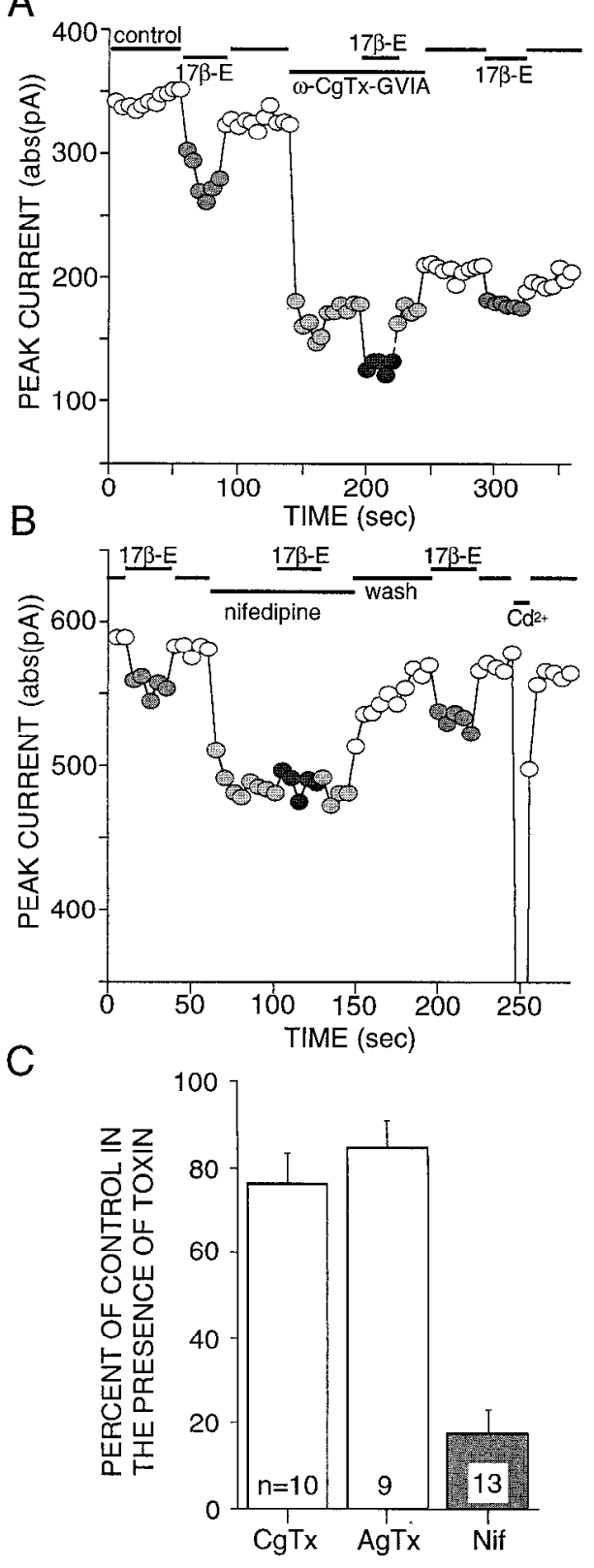

Figure 5. 17 $\beta$-Estradiol (1-100 pM) inhibited primarily nifedipinesensitive (L-type) neostriatal $\mathrm{Ca}^{2+}$ channels. $A$, In the presence of $1 \mu \mathrm{M}$ $\omega$-CTx-GVIA, estradiol was still effective in reducing $\mathrm{Ba}^{2+}$ current, suggesting that $\mathrm{N}$-type currents were not inhibited prominently by estradiol. Similar results were observed in the presence of $100 \mathrm{nM} \omega$-AgTx-IVA and $1 \mu \mathrm{m} \omega$-CTX-MVIIC (data not shown), suggesting that P-and Q-type currents also were not the principal targets of $17 \beta$-estradiol. $B$, Nifedipine $(5 \mu \mathrm{M})$, however, typically occluded the response of estradiol, suggesting that estradiol targeted primarily L-type $\mathrm{Ca}^{2+}$ channels. $C$, Statistical summary illustrating the ability of $\omega$-CTX-GVIA $(C g T x)$, $\omega$-AgTx-IVA $(A g T x)$, or nifedipine ( $N i f$ ) to occlude the effect of $17 \beta$-estradiol. The toxin data suggest that $-80 \%$ of the current inhibited by estradiol was sensitive to nifedipine. 
statistics were used to compare the effectiveness of $17 \alpha$ - and $17 \beta$-estradiol The ability of estrone, estriol, 2-methoxyestriol, 4-hydroxyestradiol, and tamoxifen to reduce $\mathrm{Ba}^{2+}$ currents was compared with $17 \beta$-estradiol using a within-subjects $t$ test. The percent recovery of cstradiol block in the presence of GTP $\gamma \mathrm{S}$ was compared with neurons dialyzed with normal GTP using a between-subjects $t$ test; $n$ values indicate the number of neurons tested.

\section{RESULTS}

\section{$17 \beta$-Estradiol reduces neostriatal $\mathrm{Ba}^{2+}$ currents}

When applied directly to neostriatal neurons, $17 \beta$-estradiol decreased $\mathrm{Ba}^{2+}$ currents evoked by depolarization within seconds of administration but did not alter "resting" conductances at $-80 \mathrm{mV}$. The modulation was readily reversible by washing. The effects of $17 \beta$-estradiol occurred at physiological concentrations (Fig. $2 A$ ). The reduction by $17 \beta$-estradiol on $\mathrm{Ba}^{2+}$ currents was observed in both acutely dissociated and primary cultured neostriatal neurons, suggesting that the enzymatic treatment of the acutely isolated cells was not responsible for the actions of the hormone (Fig. $2 B$ ). The magnitude of the $\mathrm{Ba}^{2+}$ current reduction by $17 \beta$-estradiol was similar in size to that observed when neostriatal dopamine or acetylcholine receptors are stimulated (Howe and Surmeier, 1995; Surmeier et al., 1995) and was in the range of effects observed when other neuromodulators are applied to neurons excised from central ncrvous system tissuc.

The effects of $17 \beta$-estradiol were sex-dependent. Although neostriatal neurons taken from both male and female rats were affected by $17 \beta$-estradiol, the modulation was significantly greater $(p<0.0001)$ in tissue taken from female rats $(15.11 \pm 1.9 \%, n=$ 20 from 4 females vs $7.28 \pm 0.8 \%, n=29,8$ males; Fig. $2 C$ ). The current sensitive to $17 \beta$-estradiol activated rapidly $(\sim 3 \mathrm{msec})$ and displayed little to no inactivation with $\mathrm{Ba}^{2+}$ as the charge carrier (Fig. $2 D, E$ ).

Often, the reduction in peak current by $17 \beta$-estradiol diminished with repeated application. There are two potential explanations for this result: desensitization of the estrogen-signaling pathway, or nonspecific rundown of estrogen-sensitive currents. To help determine which mechanism was responsible, $17 \beta$-estradiol was applied at periodic intervals and the modulation was monitored. Shown in Figure $3 A$ is a plot of peak current as a function of time in a neuron in which the modulation by estradiol diminished with repeated application. Two measurements were taken from this time course: the amplitude of the estradiol modulation and the amplitude of the "resistant" current (i.e., that portion of the current left in the presence of $17 \beta$-estradiol). The measurements from this cell and from five others are plotted as a function of time in Figure $3 B$. This plot shows that although the $17 \beta$-estradiol tended to diminish with time, the resistant current did not, suggesting that rundown of the $17 \beta$-estradiol-sensitive current, rather than desensitization, was responsible for the change. We cannot exclude completely, however, the possibility that desensitization occurred in parallel with rundown. Of the currents $\mathrm{cx}-$ pressed by neostriatal neurons, L-type currents are particularly susceptible to rundown, suggesting that these currents are targeted by the $17 \beta$-estradiol modulation.

\section{$17 \beta$-Estradiol modulates L-type $\mathrm{Ca}^{2+}$ channels}

To characterize better the currents affected by estradiol, membrane-permeability estimates were generated using the Goldman-Hodgkin-Katz constant-current equation (Hille, 1994). The permeability estimates of the $17 \beta$-estradiol-sensitive current then were fit with a Boltzmann function (Fig. 4A,B). The steady-state voltage dependence of the estradiol-sensitive current was consistent with it being composed of N-, P-, or L-type currents (Bargas et al., 1994). To determine which of these currents was being modulated, occlusion experiments with channel-specific antagonists were performed. The P-type- and N-type-channel toxins $\omega$-AgTx-IVA $(100 \mathrm{nM})$ and $\omega$-CTX-GVIA $(1 \mu \mathrm{M})$ only partially occluded the effects of $17 \beta$-estradiol (Fig. $5 A, C$ ). Experiments using the mixed $\mathrm{N}$ - and $\mathrm{O}$-type $\mathrm{Ca}^{2+}$-channel toxin $\omega$-CTx-MVIIC (1 $\mu \mathrm{M})$ yielded similar results $(n=4$; data not shown). However, nifedipine $(5 \mu \mathrm{M})$, an L-type-channel antagonist, produced a much stronger occlusion of the response to $17 \beta$-estradiol, suggesting that $17 \beta$-estradiol targeted primarily L-type currents (Fig. $5 B, C)$.

\section{The actions of estradiol are steroid-specific}

The effects of $17 \beta$-estradiol were dose-dependent, with a maximal reduction of $\mathrm{Ba}^{2+}$ currents occurring at $100 \mathrm{pM}$ (concentrations of $10 \mathrm{~nm}$ and $1 \mu \mathrm{M}$ did not reduce the current further). $17 \alpha$-Estradiol, the stereoisomer of the endogenous $17 \beta$ estradiol (considered to be physiologically inactive at the intracellular estrogen receptor), also was found to reduce $\mathrm{Ba}^{2+}$ currents. However, the reduction by $17 \alpha$-estradiol was significantly less $(p<0.002)$ than that of $17 \beta$-estradiol (Fig. 6A). Th: ability of other estrogenic compounds to reduce neostriatal $\mathrm{Ba}^{2+}$ currents is summarized in Figure $6 B$ (steroids were tested at $100 \mathrm{pm}$ ). The hydroxylated analog of $17 \beta$-estradiol, estriol
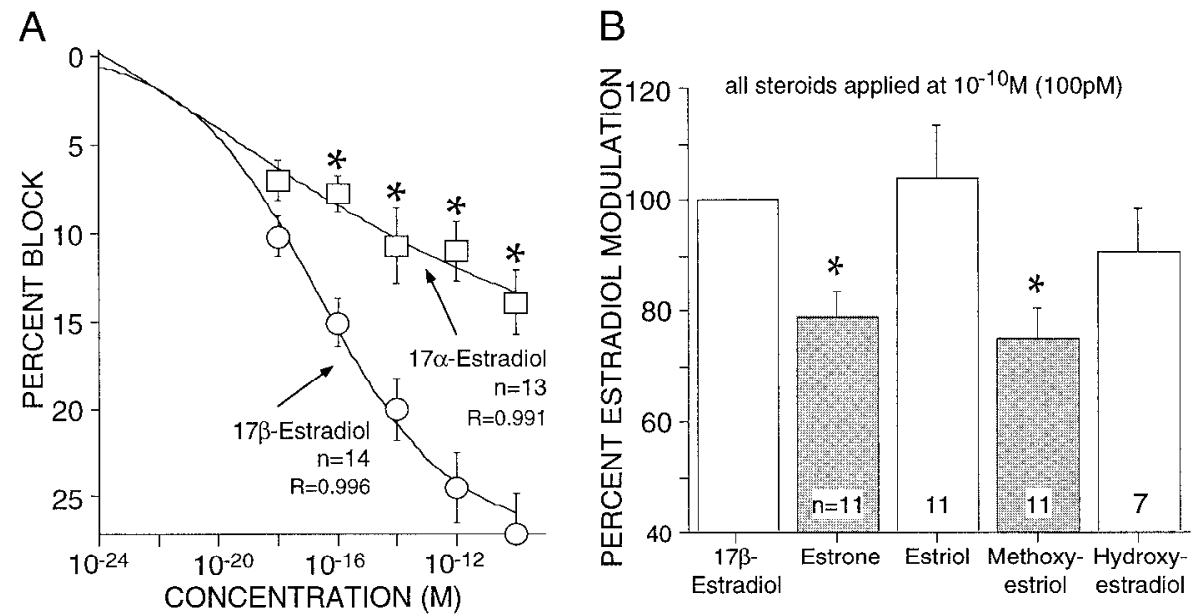

Figure 6. Inhibition of $\mathrm{Ba}^{2+}$ currents by $17 \beta-$ estradiol was steroid-specific and dose-dependent. $A, 17 \alpha$-Estradiol reduced $\mathrm{Ca}^{2+}$ currents but was significantly less effective than $17 \beta$-estradiol $(p<$ 0.002 ). The cffect of $17 \beta$-cstradiol was doscdependent, with maximal responses occurring at 100 pM. A Hill plot derived from the doseresponse data of $17 \beta$-estradiol indicated a slope factor of $0.17(R>0.999$; data not shown). $B$, Compared with $17 \beta$-estradiol, estriol and 4-hydroxyestradiol were equally effective in reducing $\mathrm{Ba}^{2+}$ currents; estrone and 2-methoxyestriol were significantly less effective $(p<0.002)$. Each steroid was applied at a concentration of $10^{-10} \mathrm{M}$ (100 pM). 
$(103.8 \pm 9.4 \%$ as effective as $17 \beta$-estradiol; $n=11)$, and 4-hydroxyestradiol $(90.6 \pm 7.6 \% ; n=7)$ were equally effective in reducing $\mathrm{Ba}^{2+}$ currents. Estrone $(78.7 \pm 4.8 \% ; n=11)$ and 2-methoxyestriol $(74.8 \pm 5.7 \% ; n=11)$, on the other hand, were significantly less effective $(p<0.002)$. Tamoxifen $(100$ $\mathrm{pM})$, considered to bc an antagonist at the intracellular estrogen receptor, was found to reduce $\mathrm{Ba}^{2+}$ currents as well (11.7 $\pm 1.3 \%$ reduction of maximal current; $n=17$ ), although significantly less $(p<0.005)$ than $17 \beta$-estradiol. Moreover, tamoxifen only slightly occluded the inhibition of $17 \beta$-estradiol on $\mathrm{Ba}^{2+}$ currents $(18.0 \pm 8.2 \% ; n=10)$.

\section{$17 \beta$-Estradiol acts at a surface receptor}

$17 \beta$-Estradiol appears to reduce $\mathrm{Ba}^{2+}$ currents by acting at the membrane surface, not on an intracellular receptor. E-BSA, which cannot penetrate the cellular membrane, also was found to inhibit $\mathrm{Ba}^{2+}$ currents (Fig. $7 A, B$ ). In this E-BSA, estradiol was conjugated on the 17 th carbon. Because the inhibition of $17 \alpha$-estradiol on $\mathrm{Ba}^{2+}$ currents was significantly less than that of $17 \beta$-estradiol (Fig. $6 A$ ), it was unclear whether the efficacy of E-BSA was caused, at least in part, by the presence of free estradiol. To verify that $17 \beta$-estradiol acts at the membranc surface, a subset of cells was intracellularly perfused with $17 \beta$-estradiol. $17 \beta$-Estradiol was allowed to diffuse into the cell for at least 5 min before we applied $17 \beta$-estradiol externally (time between membrane rupture and recording). Based on estimates of dialysis times for similar compounds with cells similar in size to ours (Pusch and Neher, 1988), the concentration of estradiol in the cell interior and the electrode should have equilibrated in this period. After dialysis, $17 \beta$-estradiol (1 pM) applied extracellularly still inhibited $\mathrm{Ba}^{2+}$ currents (Fig. $7 C$ ).

The inhibition of $\mathrm{Ba}^{2+}$ currents by $17 \beta$-estradiol appeared to depend on activation of a $\mathrm{G}$-protein. Under normal conditions, the $17 \beta$-estradiol modulation readily reversed when the hormone was removed $(70.4 \pm 10.0 \%$ of the current blocked by $17 \beta-$ estradiol reversed after return to the control solution; $n=7$, Fig. $8 B)$. However, when the cell was dialyzed with GTP $\gamma \mathrm{S}(400 \mu \mathrm{M})$ recovery after $17 \beta$-estradiol removal was significantly $(p<0.05)$ reduced $(40.5 \pm 10.9 \%, n=8$; Fig. $8 A, B)$. This pattern suggests that $17 \beta$-estradiol activates a $G$-protein in a signaling pathway targeting $\mathrm{Ca}^{2+}$ channels.

G-proteins are capable of modulating $\mathrm{Ca}^{2+}$ channels either via cytosolic second-messenger pathways or via direct interaction with the channel or an associated protein (Hille, 1992a). This latter signaling pathway often is referred to as membranedelimited. A common characteristic of membrane-delimited inhibition of $\mathrm{Ba}^{2+}$ currents is the ability of strong membrane depolarization to reverse the modulation temporarily. To test whether the pathway mediated by the effects of $17 \beta$-estradiol shared this property, agonist was applied with and without a brief $(30 \mathrm{msec})$ depolarizing $(100 \mathrm{mV})$ prepulse. The modulation of $\mathrm{Ba}^{2+}$ currents by $17 \beta$-estradiol was unaffected by the strong prepulse [the modulation after a prepulse was $100.6 \pm$ $4.6 \%(n=22)$ of the control; Fig. $9 A-C]$, suggesting that inhibition of $\mathrm{Ba}^{2+}$ currents by $17 \beta$-estradiol was not mediated by a membrane-delimited $\mathrm{G}$-protein interaction.

The impact of intracellular $\mathrm{Ca}^{2+}$ on the effects of $17 \beta$ estradiol was examined by varying the concentration of the $\mathrm{Ca}^{2+}$ chelator BAPTA in the patch-pipette solution. Typically, neostriatal neurons were studied with the intracellular $\mathrm{Ca}^{2+}$ concentration at low nanomolar levels by recording with an
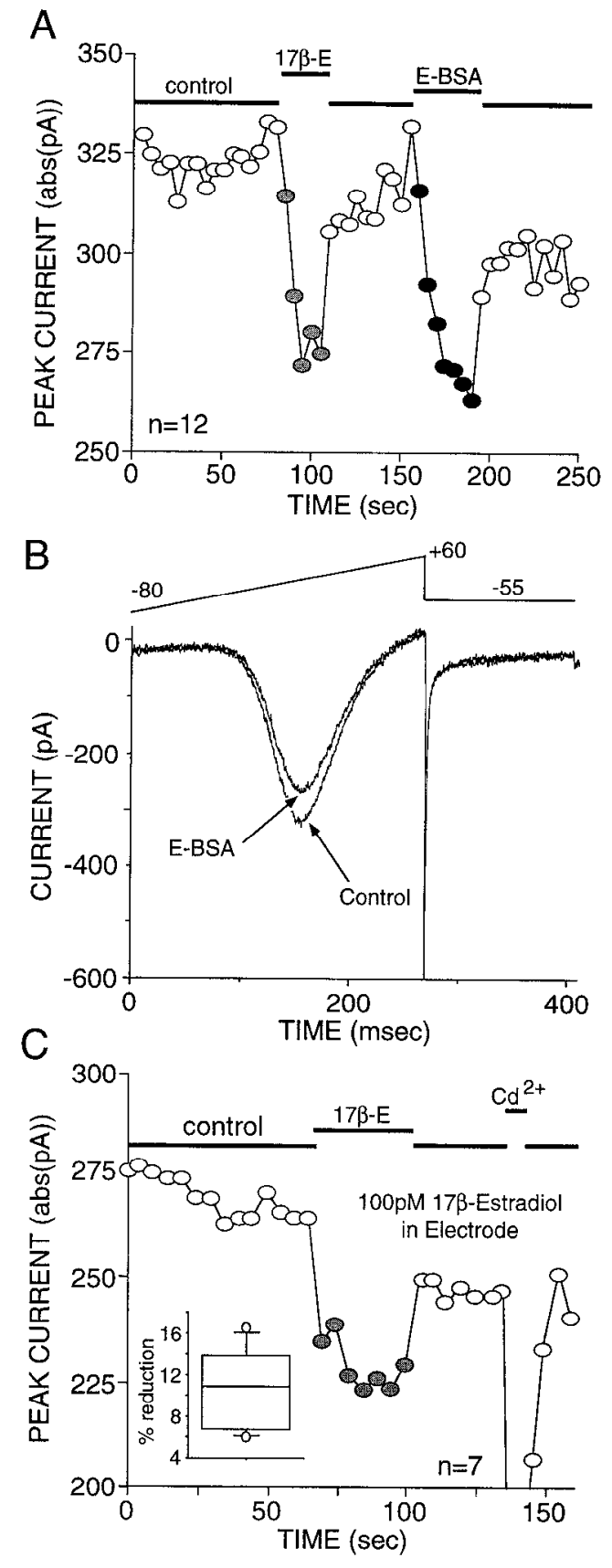

Figure 7. The effects of $17 \beta$-estradiol occur at the cellular membrane. $A$, E-BSA (52 pM) also was found to inhibit neostriatal $\mathrm{Ba}^{2+}$ currents, suggesting that the immediate actions of $17 \beta$-estradiol occur at the membrane surface. The administration of $17 \beta$-estradiol ( $52 \mathrm{pM}$ ) and E-BSA produced a sirnilar reduction in current. $B$, Individual traces taken from the time course shown in $A$. C, Dialyzing the inside of the cell with $17 \beta$-estradiol (100 pM) did not influence the response to $17 \beta$-estradiol (1 pM) administered externally, suggesting an effect at the extracellular face of the membrane. Inset, Statistical summary of the percent reduction of the whole-cell $\mathrm{Ba}^{2+}$ current inhibited by $1 \mathrm{pM} 17 \beta$-estradiol after intracellular dialysis.

internal solution containing 5-10 mM BAPTA and no added $\mathrm{Ca}^{2+}$. When the BAPTA concentration was lowered to $0.1 \mathrm{~mm}$ to allow fluctuations in intracellular $\mathrm{Ca}^{2+}$, no change in the magnitude of the modulation by $17 \beta$-estradiol was observed $[15.5 \pm 2.7 \%(n=12)$ reduction of the whole-cell currents by 
A

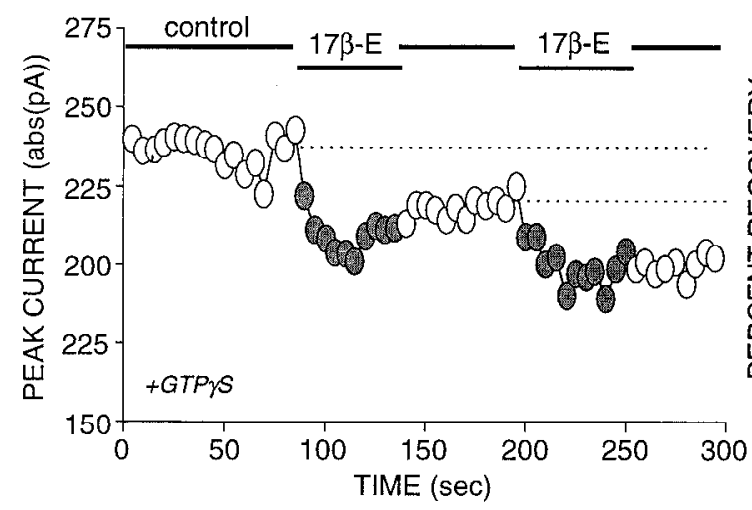

B

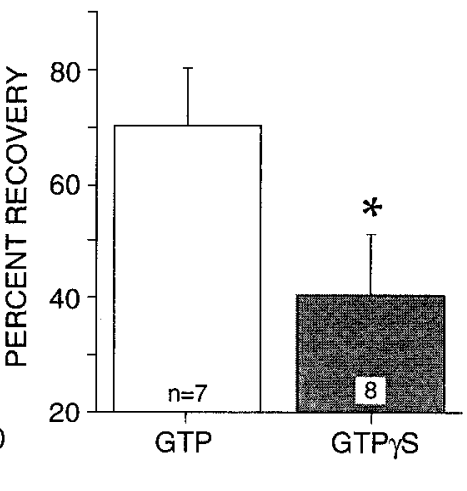

Figure 8. $17 \beta$-Estradiol inhibition of neostriatal $\mathrm{Ba}^{2+}$ currents appeared to occur via G-protein activation. $A$, Time course of $17 \beta$-estradiol ( 100 pM) modulation in a neostriatal neuron dialyzed with GTP $\gamma \mathrm{S}$. In the presence of GTP $\gamma \mathrm{S}$, the effect of $17 \beta$-estradiol did not reverse readily with removal of agonist, in contrast to the situation with GTP dialysis. B, Statistical summary of the percent recovery when the neuron was dialyzed with either GTP $(200 \mu \mathrm{M})$ or GTP $\gamma \mathrm{S}(400 \mu \mathrm{M})$. The effects of estradiol were less likely to reverse in neurons perfused with GTP $\gamma \mathrm{S}(p<0.05)$. estradiol with $0.1 \mathrm{~mm}$ BAPTA vs $14.9 \pm 2.8 \%(n-8)$ with 10 mM BAPTA]. This finding suggests that $17 \beta$-estradiol does not require an elevation of intracellular $\mathrm{Ca}^{2+}$ to inhibit voltageactivated currents (Fig. 7D).

\section{DISCUSSION}

These results demonstrate that physiological concentrations of $17 \beta$-estradiol rapidly reduce L-type currents in neostriatal neurons. This modulation was sex-specific in that $17 \beta$-estradiol was more effective in neurons acquired from female rats than those from males. The effect was also steroid-specific: $17 \alpha$-estradiol, estrone, and 2-methoxyestriol were less effective in modulating $\mathrm{Ba}^{2+}$ currents than $17 \beta$-estradiol. Finally, these effects appeared to be mediated by a G-protein-coupled receptor at the membrane surface.

One difference between our results and previous reports is the steroid concentrations required to elicit maximal effects. In hippocampal neurons, micromolar concentrations of corticosteroids are required to maximally reduce $\mathrm{Ba}^{2+}$ currents (ffrench-Mullen and Spence, 1991; ffrench-Mullen et al., 1994; ffrench-Mullen, 1995). Although some steroids may be synthesized within the brain and reach micromolar concentrations (Corpechot et al., 1983; Lanthier and Patwardham, 1986; Baulieu and Robel, 1990), there is no evidence that this is the case for estrogen. We found that $17 \beta$-estradiol was maximally effective in inhibiting $\mathrm{Ca}^{2+}$ channels at picomolar concentrations, close to those concentrations found in the blood of late proestrus rats (Smith et al., 1975). Although the effects of $17 \beta$-estradiol were dose-dependent, extremely low concentrations of the hormone also produced reduction of $\mathrm{Ba}^{2+}$ currents. The ability of lower concentrations of $17 \beta$-estradiol to modulate currents may be attributable to the lipophilic properties of the steroid and the experimental paradigm. The membrane of a dissociated neuron may act as an "estrogen sink," raising the concentration in the membrane several log units above that in the aqueous phase (Stein, 1986). How partitioning is regulated in situ is a question of obvious importance for determining the physiological impact of circulating estrogen. However, the dose response also is complicated by the fact that $17 \beta$-estradiol appears to reduce $\mathrm{Ba}^{2+}$ currents via $\mathrm{G}$-protein activation.

Although it appears $17 \beta$-estradiol reduces $\mathrm{Ba}^{2+}$ currents via a receptor embedded in the cellular membrane, the steroidbinding site need not be on the external face. The binding site may be within the outer membrane layer of the cell. Externally applied $17 \beta$-estradiol should enter and diffuse quickly within this external lipid leaflet, only slowly "flipping" into the inter- nal lipid layer. The fact that dialyzing neostriatal neurons intracellularly with $17 \beta$-estradiol has no apparent influence on the effectiveness of externally applied $17 \beta$-estradiol is consistent with this model. Although the magnitude of the modulation by $17 \beta$-estradiol was somewhat less when the cell was intracellularly dialyzed with this steroid, this phenomenon likely is caused by our waiting at least $5 \mathrm{~min}$ between cell rupture and recording. As shown in Figure 3, the effect of $17 \beta$-estradiol decreases over time.

The ability to reverse rapidly the effects of $17 \beta$-estradiol with washing also suggests that the binding site is not energetically remote from the external medium. By analogy, nifedipine, also a lipophilic compound, blocks L-type $\mathrm{Ca}^{2+}$ channels by binding to a channel site accessible from within the membrane, rather than a site approached from the mouth of the pore (Hille, $1992 \mathrm{~b}$ ). The effects of nifedipine, like those of $17 \beta$-estradiol, can be rapidly reversed with our perfusion system after drug removal (see Fig. 3).

$\Lambda \mathrm{n}$ argument for the effect of $17 \beta$ estradiol being mediated by a specific estrogen receptor is that the modulation was both stereospecific and steroid-specific. $17 \alpha$-Estradiol was considerably less effective than $17 \beta$-estradiol. Estrone and 2 -methoxyestriol also were less effective than $17 \beta$-estradiol. However, estriol and 4-hydroxyestradiol, two steroids with an additional hydroxyl group, were equally effective. Apparently, there is more than one site on the estrogen molecule important for receptor activation. Estriol is hydroxylated at carbon 16, whereas 4-hydroxyestradiol is hydroxylated at carbon 4 . Neither of these alterations appeared to affect the efficacy of the steroid. Moreover, estrone differs from $17 \beta$-estradiol at carbon 17 , and 2-methoxyestriol differs from estriol at carbon 2; yet both were less effective than $17 \beta$-estradiol in reducing currents. The data suggest that if $17 \beta$-estradiol is binding to a membrane receptor, then it can interact with both sides of the molecule. The binding of steroids to the intracellular estrogen receptor exhibits similar properties (i.e., lack of site specificity) (Anderson et al., 1975; Davies et al., 1975; Martucci and Fishman, 1979; Kirchhoff et al., 1984). However, it should be noted that binding cannot be equated readily to receptor activation.

At equimolar concentrations, tamoxifen did not antagonize the effects of $17 \beta$-estradiol effectively. Although tamoxifen and its metabolites generally are considered to be antagonists at the intracellular receptor, tamoxifen also can induce estrogenic effects (Jordan, 1984; Jordan and Murphy, 1990). It has been reported also that tamoxifen has cellular actions independent 

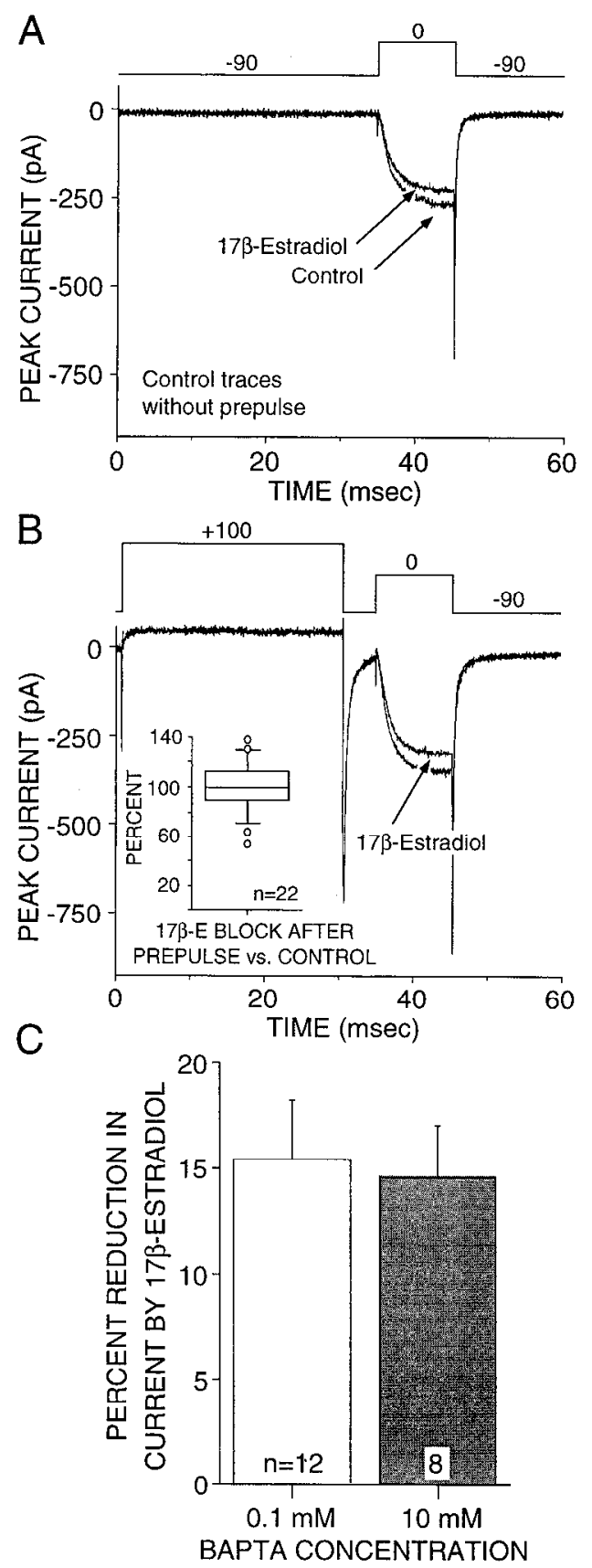

Figure 9. The modulation by $17 \beta$-estradiol was neither voltagedependent nor intracellular $\mathrm{Ca}^{2+}$ chelation-dependentl. $A, \mathrm{Ba}^{2+}$ currents evoked by a step to $0 \mathrm{mV}$ from a holding potential of $-90 \mathrm{mV}$ in the presence and absence of estradiol $(1 \mathrm{pM}), B, \mathrm{Ba}^{2+}$ currents evoked by a step to $U \mathrm{mV}$ when preceded by a $30 \mathrm{msec}$ prepulse to $+100 \mathrm{mV}$. Note that the estradiol modulation is unaffected by the prepulse. Inset, Box-plot summary of the percent modulation after the depolarizing prepulse (compared with control modulation). $\mathrm{Cd}^{2+}$-insensitive currents were subtracted from all traces. $C$, Variation in the intracellular concentration of the $\mathrm{Ca}^{2+}$ chelator BAPTA did not alter the magnitude of the modulation by $17 \beta$-estradiol, suggesting that the second-messenger pathway by which $17 \beta$-estradiol inhibits $\mathrm{Ca}^{2+}$ channels is $\mathrm{Ca}^{2+}$-independent. Shown are the percent reductions in peak current produced by $17 \beta$-estradiol (at least 1 pM) in recordings with 0.1 and $10 \mathrm{~mm} \mathrm{BAPTA}$ dialysates (no added $\mathrm{Ca}^{2+}$ ). Bars are SEM.

of estrogen receptors. For example, there are specific, highaffinity binding sites for tamoxifen in rat brain (Sudo et al., 1983; Gray and Ziemian, 1992). Also, tamoxifen inhibits pro- tein kinase C. (O'Brian et al., 1985; Su et al., 1985; Issandon et al., 1990) and, at high concentrations, competes for neostriatal dopamine receptors (Hiemke and Ghraf, 1984). These observations are consistent with the partially additive effects of tamoxifen and $17 \beta$-estradiol in modulating $\mathrm{Ba}^{2+}$ currents observed in this study.

Often, it is assumed that activation of intracellular steroid receptors results in long-term changes in gene expression. Nongenomic actions, on the other hand, are believed to be rapid in onset but fleeting in duration. However, this may not necessarily be true. L-Type $\mathrm{Ca}^{2+}$ channels are found primarily in somatic and proximal dendritic membrane (Westenbroek et al., 1990; Hell et al., 1993). By decreasing L-type currents, $17 \beta$-estradiol may affect the spike generation and patterning of the neuron, but also gene transcription (Murphy ct al., 1991; Bading et al., 1993). Moreover, G-protein activation may induce long-term intracellular changes via phosphorylation. Therefore, the nongenomic actions of $17 \beta$-estradiol, although rapid in onset, also may have long-term effects on neostriatal function. Previous reports studying the nongenomic actions of $17 \beta$-estradiol within the neostriatum often have examined potentiated dopamine release, alterations in dopamine-receptor binding, and enhancement of sensorimotor responses. Future experiments will examine whether activation of the G-protein, second-messenger cascade by $17 \beta$-estradiol reported in this study is related to these other effects.

Of interest, the reduction of $\mathrm{Ba}^{2+}$ currents by $17 \beta$-estradiol was somewhat faster (maximal effects occurred after several seconds) when applied directly to neostriatal neurons than that reported previously when $17 \beta$-estradiol was applied to slices (several minutes) (Nabckura et al., 1986; Becker, 1990a). Moreover, changes that occur when estradiol is administered in vivo take somewhat longer (15 minutes to several hours) (Becker et al., 1987; Levesque and Di Paolo, 1988; Bazzett and Becker, 1994). The onset of the effects from $17 \beta$-estradiol likely is a reflection of the delivery mechanism used in each experiment.

$17 \beta$-Estradiol was effective in reducing $\mathrm{Ba}^{2+}$ currents in nearly all neurons tested. Recorded cells displayed the morphology and surface area typical of medium spiny projection neurons. Projection neurons in the neostriatum, however, are not homogeneous: one group projects to the globus pallidus, whereas the other projects to both the globus pallidus and the substantia nigra (Kawaguchi et al., 1990; Gerfen, 1992). The neostriatum can be subdivided further with anatomical markers into patch and matrix compartments (Pert et al., 1976; Gerfen et al., 1985; Bolam et al., 1988; Gerfen, 1989). Because a vast majority of neurons were affected by $17 \beta$-estradiol, it is likely that neurons from each of these anatomical groupings are estrogen-sensitive. Future studies will determine whether the response to $17 \beta$-estradiol differs between these different types of neurons, an important consideration when attempting to understand how $17 \beta$-estradiol affects basal ganglia functioning.

Aside from the involvement of a G-protein, the signaling mechanism by which estrogen reduces $\mathrm{Ba}^{2+}$ currents must await further study. L-Type channels can be modulated via several discrete mechanisms in neostriatal neurons. $\mathrm{D}_{1}$ dopamine agonists, for example, enhance L-type currents via a protein kinase A cascade involving a pertussis toxin (PTX)-insensitive G-protein and adenylyl cyclase (Surmeier et al., 1995). On the other hand, muscarinic agonists inhibit L-type currents via a pathway involving a PTX-insensitive G-protein (Howe and Surmeier, 1995). This pathway appears to depend on the release of inositol triphos- 
phates $\left(\mathrm{IP}_{3}\right)$ and the release of intracellular $\mathrm{Ca}^{2+}$. Of interest, estrogen also has been shown to increase $\mathrm{IP}_{3}$ synthesis in other cell types (Morley et al., 1992). However, 17 $\beta$-estradiol was effective in reducing $\mathrm{Ba}^{2+}$ currents through $\mathrm{Ca}^{2+}$ channels when the intracellular $\mathrm{Ca}^{2+}$ was chelated to low nanomolar levels, suggesting that $17 \beta$-estradiol is acting via a second-messenger system not involved with the release of intracellular $\mathrm{Ca}^{2+}$.

It is important to determine the relationship between the reduction by $17 \beta$-estradiol on $\mathrm{Ca}^{2+}$ currents and other estrogenmediated changes in rat neostriatum. The role of neostriatal dopamine neurotransmission on locomotor behavior is well documented. Because $\mathrm{Ca}^{2+}$ is crucial for neurotransmitter release and modifies intracellular changes induced by receptor activation, the question remains whether the reduction of $\mathrm{Ca}^{2+}$ currents by $17 \beta$-estradiol is responsible for the effects observed previously on neostriatal dopaminergic systems and behaviors. Future studies will determine whether these phenomena are causally related.

In summary, $17 \beta$-estradiol reduces neostriatal $\mathrm{Ba}^{2+}$ currents through $\mathrm{Ca}^{2+}$ channels via activation of a G-protein-signaling pathway. The effect is greater in female neostriatal neurons than in cells taken from male rats, and the magnitude of the reduction is steroid-specific. These effects occur at physiological concentrations and may play an important role in alterations in motor performance during different stages of the estrus cycle.

\section{REFERENCES}

Anderson JN, Peck EJ, Clark JH (1975) Estrogen-induced uterine responses and growth: relationship to receptor estrogen binding by uterine nuclei. Endocrinology 96:160-167.

Arnauld E, Dufy B, Pestre M, Vincent JD (1981) Effects of estrogen on the responsiveness of caudate neurons to microiontophoretically applied dopamine. Neurosci Lett 21:325-331.

Bading H, Ginty DD, Greenberg ME (1993) Regulation of gene expression in hippocampal neurons by distinct calcium signaling pathways. Science 260:181-186.

Bargas J, Howe A, Eberwine J, Cao Y, Surmeier DJ (1994) Cellular and molecular characterization of $\mathrm{Ca}^{2+}$ currents in acutely isolated adult rat neostriatal neurons. J Neurosci 14:6667-6686.

Baulieu EE, Robel P (1990) Neurosteroids: a new brain function. J Steroid Biochem Mol Biol 37:395-403.

Bazzett TJ, Becker JB (1994) Sex differences in the rapid and acute effects of estrogen on striatal $\mathrm{D}_{2}$ dopamine receptor binding. Brain Res 637:163-172.

Becker JB (1990a) Direct effect of $17 \beta$-estradiol on striatum: sex differences in dopamine release. Synapse 5:157-164.

Becker JB (1990b) Estrogen rapidly potentiates amphetamine-induced striatal dopamine release and rotational behavior during microdialysis. Neurosci Lett 118:169-171.

Becker JB, Snyder PJ, Miller MM, Westgate SA, Jenuwine MJ (1987) The influence of estrous cycle and intrastriatal estradiol on sensorimotor performance in the female rat. Pharmacol Biochem Behav 27:53-59.

Berthois Y, Katzenellenbogen JA, Katzenellenbogen BS (1986) Phenol red in tissue culture media is a weak estrogen: implications concerning the study of estrogen-responsive cells in culture. Proc Natl Acad Sci USA 83:2496-2500.

Bolam JP, Izzo PN, Graybiel AM (1988) Cellular substrate of the histochemically defined striosome/matrix system of the caudate nucleus: a combined Golgi and immunocytochemical study in cat and ferret. Neuroscience 24:853-875.

Carson-Jurica MA, Schrader WT, O'Malley BW (1990) Steroid receptor family: structure and functions. Endocr Rev 11:201-220.

Castner SA, Xio L, Becker JB (1993) Sex differences in striatal dopamine: in vivo microdialysis and behavioral studies. Brain Res 610:127-134.

Clopton JK, Gordon JH (1986) In vivo effects of estrogen and 2-hydroxyestradiol on $\mathrm{D}_{2}$ dopamine receptor agonist affinity states in rat striatum. J Neural Transm 66:13-20.

Corpechot C, Synguelakis M, Talha S, Axelson M, Sjovall J, Vihko R, Baulieu EE, Robel P (1983) Pregnenolone and its sulfate ester in the rat brain. Brain Res 270:119-125.
Davies IJ, Naftolin F, Ryan KJ, Fishman J, Siu J (1975) The affinity of catechol estrogens for estrogen receptors in the pituitary and anterior hypothalamus of the rat. Endocrinology 97:554-557.

Demotes-Mainard J, Arnauld E, Vincent JD (1990) Estrogens modulate the responsiveness of in vivo recorded striatal neurons to iontophoretic application of dopamine in rats: role of $D_{1}$ and $D_{2}$ receptor function. $J$ Neuroendocrinol 2:825-832.

Dufy B, Vincent J-D, Fleury H, DuPasquier P, Gourdji D, Tixier-Vidal A (1979) Membrane effects of thyrotropin-releasing hormone and estrogen shown by intracellular recording trom pituitary cells. Science 204:509-511.

ffrench-Mullen JMH (1995) Cortisol inhibition of calcium currents in guinea pig hippocampal CA1 neurons via G-protein-coupled activation of protein kinase C. J Neurosci 15:903-911.

french-Mullen JMH, Spence KT (1991) Neurosteroids block $\mathrm{Ca}^{2+}$ channel current in freshly isolated hippocampal CA1 neurons. Eur J Pharmacol 202:269-272.

french-Mullen JMH, Danks P, Spence KT (1994) Neurosteruids modulate calcium currents in hippocampal CA1 neurons via a pertussis toxin-sensitive. G-protein-coupled mechanism. J Neurosci 14:1963-1977.

Gerfen CR (1989) The neostriatal mosaic: striatal patch-matrix organization is related to cortical lamination. Science 246:385-388.

Gerfen CR (1992) The neostriatal mosaic: multiple levels of compartmental organization. Trends Neurosci 15:133-139.

Gerfen CR, Baimbridge KG, Miller JJ (1985) The neostriatal mosaic: compartmental distribution of calcium-binding protein and parvalbumin in the basal ganglia of the rat and monkey. Proc Natl Acad Sci USA 82:8780-8784.

Gordon JH, Perry KO (1983) Pre- and postsynaptic neurochemical alterations following estrogen-induced striatal dopamine hypo- and hypersensitivity. Brain Res Bull 10:425-428.

Gray JM, Ziemian L (1992) Antiestrogen binding sites in brain and pituitary of ovariectomized rats. Brain Res 578:55-59.

Hamill OP, Marty A, Neher E, Sakmann B, Sigworth FJ (1981) Improved patch-clamp techniques for high resolution current recording from cells and cell-free membrane patches. Pflügers Arch 391:85 100.

Hell JW, Westenbroek RE, Warner C, Ahlijanian MK, Prystay W, Gilber MM, Snutch TP, Catterall WA (1993) Identification and differential subcellular localization of the neuronal class C and class D L-type calcium channel $\alpha 1$ subunits. J Cell Biol 123:949-962.

Hille B (1992a) G-Protein coupling mechanisms and nervous system signaling. Neuron 9:187-195.

Hille B (1992b) Ionic channels of excitable membranes. Sunderland, MA: Sinauer.

Hiemke C, Ghraf R (1984) Interaction of non-steroidal antiestrogens with dopamine receptor binding. J Steroid Biochem Mol Biol 21:663-667.

Howe A, Surmeier DJ (1995) Muscarinic receptors modulate N-, P-, and $\mathrm{L}$-type $\mathrm{Ca}^{2+}$ currents in rat striatal neurons through parallel pathways. J Neurosci 15:458-469.

Issandou M, Faucher C, Bayard F, Darbon JM (1990) Opposite effects of tamoxifen on in vitro protein kinase $\mathrm{C}$ activity and endogenous protein phosphorylation in intact MCF-7 cells. Cancer Res 50:5845-5850.

Jordan VC (1984) Biochemical pharmacology of antiestrogen action. Pharmacol Rev 36:245-276.

Jordan VC, Murphy CS (1990) Endocrine pharmacology of antiestrogens as antitumor agents. Endocr Rev 11:578-610.

Kawaguchi Y, Wilson CJ, Emson PC (1990) Projection subtypes of rat neostriatal matrix cells revealed by intracellular injection of biocytin. $\mathbf{J}$ Neurosci 10:3421-3438.

Kelly MJ, Moss RL, Dudley CA (1977) The effects of microelectrophoretically applied estrogen, cortisol and acetylcholine on medial preoptic-septal unit activity throughout the estrous cycle of the female rat. Exp Brain Res 30:53-64.

Kelly MJ, Loose MD, Ronnekleiv OK (1992) Estrogen suppresses $\mu$-opioid- and $\mathrm{GABA}_{\mathrm{B}}$-mediated hyperpolarization of hypothalamic arcuate neurons. J Neurosci 12:2745-2750.

Kirchhoff J, Wang X, Ghraf R, Ball P, Knuppen R (1984) Interactions of methylestrogens with cytoplasmic and nuclear estrogen receptors in rat pituitary gland, hypothalamus and uterus. Brain Res 294:354-358.

Lanthier A, Patwardham VV (1986) Sex steroids and 5- $n-3 b$ hydroxysteroids in specific regions of the human brain and cranial nerves. J Steroid Biochem Mol Biol 25:445-449. 
Levesque D, Di Paolo T (1988) Rapid conversion of high into low striatal $\mathrm{D}_{2}$-dopamine receptor agonist binding states after an acute physiological dose of 17 $\beta$-estradiol. Neurosci Lett 88:113-118.

Martucci C, Fishman J (1979) Impact of continuously administered catechol estrogen on uterine growth and LH secretion. Endocrinology 105:1288-1292.

McEwen BS (1979) Steroid hormone interactions with the brain: cellular and molecular aspects. Rev Neurosci 4:1-30.

Minami T, Oomura Y, Nabekura J, Fukuda A (1990) 17ß-Estradiol depolarization of hypothalamic neurons is mediated by cyclic AMP. Brain Res 519:301-307.

Morley P, Whitfield JF, Vanderhyden BC, Tsang BK, Schwartz J-L (1992) A new, nongenomic estrogen action: the rapid release of intracellular calcium. Endocrinology 131:1305-1312.

Murphy TH, Worley PF, Baraban JM (1991) L-Type voltage-sensitive calcium channels mediate synaptic activation of immediate early genes. Neuron 7:625-635.

Nabekura J, Oomura Y, Minami T, Mizuno Y, Fukuda A (1986) Mechanism of the rapid effect of $17 \beta$-estradiol on medial amygdala neurons. Science 233:226-228.

O'Brian CA, Liskamp RM, Solomon DH, Weinstein IB (1985) Inhibition of protein kinase $C$ by tamoxifen. Cancer Res 45:2462-2465.

Paxinos G, Watson C (1986) The rat brain in stereotaxic coordinates. San Diego, Academic.

Pert CB, Kuhar MJ, Snyder SH (1976) Opiate receptor: autoradiographic localization in the rat brain. Proc Natl Acad Sci USA 73:3729-3733.

Pfaff DW (1980) Estrogen and brain function: neural analysis of hormonecontrolled mammalian reproductive behavior. New York, Springer.

Pfaff DW, Keiner M (1973) Atlas of estradiol-concentrating cells in the central nervous system of the female rat. J Comp Neurol 151:121-158.

Pfaff DW, Schwartz-Giblin S (1988) Cellular mechanisms of female reproductive behavior: the physiology of reproduction. New York, Raven.

Pusch M, Neher E (1988) Rates of diffusional exchange between small cells and a measuring patch pipette. Pflügers Arch 411:204 211.

Simerly RB, Chang C, Muramatsu M, Swanson LW (1990) Distribution of androgen and estrogen receptor mRNA-containing cells in the rat brain: an in situ hybridization study. J Comp Neurol 294:76-95.

Smith MS, Freeman ME, Neill JD (1975) The control of progesterone secretion during the estrous cycle and early pseudopregnancy in the rat: prolactin, gonadotropin and steroid levels associated with rescue of the corpus luteum of pseudopregnancy. Endocrinology 96:219-226.

Smith SS, Waterhouse BD, Woodward DJ (1987) Sex steroid effects on extrahypothalamic CNS. I. Estrogen augments neuronal responsiveness to iontophoretically applied glutamate in the cerebellum. Brain Res 422:40-51.

Smith SS, Woodward DJ, Chapin JK (1989) Sex steroids modulate motorcorrelated increases in cerebellar discharge. Brain Res 476:307-316.
Stancel GM, Leung MT, Gorski J (1973) Estrogen receptors in the rat uterus: multiple forms produced by concentration-dependent aggregation. Biochem J 12:2130-2136.

Stein WD (1986) Transport and diffusion across cell membranes. New York, Academic.

Stumpf WE, Sar M (1978) Steroid hormone target sites in the brain: the differcntial distribution of estrogen, progestin, androgen and glucocorticosteroid. J Steroid Biochem Mol Biol 7:1163-1170.

Su H-D, Mazzei GJ, Vogler WR, Kuo JF (1985) Effect of tamoxifen, a nonsteroidal antiestrogen, on phospholipid/calcium-dependent protein kinase and phosphorylation of its endogenous substrate proteins from the rat brain and ovary. Biochem Pharmacol 34:3649-3653.

Sudo K, Monsma Jr FJ, Katzenellenbogen BS (1983) Antiestrogenbinding sites distinct from the estrogen receptor: subcellular localization, ligand specificity, and distribution in tissues of the rat. Endocrinology 112:425-434.

Surmeier DJ, Kita H, Kitai ST (1988) The expression of $\gamma$-aminobutyric acid and Leu-enkephalin immunoreactivity in primary monolayer cultures of rat striatum. Dev Brain Res 42:265-282.

Surmeier DJ, Stefani A, Foehring R, Kitai ST (1991) Developmental expression of a slowly inactivating voltage-dependent potassium current in rat neostriatal neurons. Neurosci Lett 122:41-46.

Surmeier DJ, Eberwine J, Wilson CJ, Stefani A, Kitai ST (1992) Dopamine receptor subtypes co-localize in rat striatonigral neurons. Proc Natl Acad Sci USA 89:10178-10182.

Surmeier DJ, Bargas J, Hemmings HC, Nairn AC, Greengard P (1995) Modulation of calcium currents by a $\mathrm{D}_{1}$ dopaminergic protein kinase/ phosphatase cascade in rat neostriatal neurons. Neuron 14:385-397.

Thompson TL, Moss RL (1994) Estrogen regulation of dopamine release in the nucleus accumbens: genomic- and nongenomic-mediated effects. $\mathrm{J}$ Neurochem 62:1750-1756.

Tonnaer JA, Leinders T, van Delft AM (1989) Ovariectomy and subchronic estradiol-17 $\beta$ administration decrease dopamine $D_{1}$ and $D_{2}$ receptors in rat striatum. Psychoneuroendocrinology 14:469-476.

Toran-Allerand CD, Miranda RC, Ilochberg RB, MacLusky NJ (1992) Cellular variations in estrogen receptor mRNA translation in the developing brain: evidence from combined $\left[{ }^{125} \mathrm{I}\right]$-estrogen autoradiography and non-isotopic in situ hybridization histochemistry. Brain Res 576:25-41.

Westenbroek RE, Ahlijanian MK, Catterall WA (1990) Clustering of L-type $\mathrm{Ca}^{2+}$ channels at the base of major dendrites in hippocampal pyramidal neurons. Nature 347:281-284.

Wong M, Moss RL (1991) Electrophysiological evidence for a rapid membrane action of the gonadal steroid, $17 \beta$-estradiol, on CA1 pyramidal neurons of the rat hippocampus. Brain Res 543:148-152.

Wong M, Moss RL (1992) Long-term and short-term electrophysiological effects of estrogen on the synaptic properties of hippocampal CA1 neurons. J Neurosci 12:3217-3225. 